\title{
Impact of sex and diet on hematological and blood plasma biochemical profiles and liver histology of pikeperch (Sander lucioperca (L.))
}

\author{
Zdzisław Zakęś, Krystyna Demska-Zakęś, Mirosław Szczepkowski, Maciej Rożyński, \\ Elżbieta Ziomek
}

Received - 30 March 2016/Accepted - 08 May 2016. Published online: 30 June 2016; OInland Fisheries Institute in Olsztyn, Poland Citation: Zakęś Z., Demska-Zakęś K., Szczepkowski M., Rożyński M., Ziomek E. 2016 - Impact of sex and diet on hematological and blood plasma biochemical profiles and liver histology of pikeperch (Sander lucioperca (L.)) - Arch. Pol. Fish. 24: 61-68.

\begin{abstract}
The aim of the study was to determine the impact of diet and sex on the hematological and blood plasma biochemical profiles and the liver histology of pikeperch, Sander lucioperca (L.) reared in recirculating aquaculture systems (RAS) (initial mean body weight (BW) $1.35 \mathrm{~kg}$ ). The proximate composition of the two commercial feeds used were (protein/lipid/nitrogen-free extracts) (P/L/NFE)) P505/L118/NFE294 g $\mathrm{kg}^{-1}$ (group I) and P471/L141/NFE290 $\mathrm{g} \mathrm{kg}^{-1}$ (group II). Neither diet nor sex had a significant impact on final fish body weight $(\approx 2.0 \mathrm{~kg})$. Sex was noted to significantly impact glucose content (Glu higher in males) and cholesterol (Chol - higher in females) in the blood plasma. Diet was confirmed to have a significant impact on levels of hematocrit $(\mathrm{Ht})$, hemoglobin $(\mathrm{Hb})$, and mean corpuscular hemoglobin (MCH), and the values of these indicators were higher in group I. Sex had a significant impact on $\mathrm{Ht}, \mathrm{Hb}, \mathrm{MCH}$, and mean corpuscular hemoglobin concentration (MCHC), with higher values in male pikeperch.
\end{abstract}

\footnotetext{
Z. Zakęś [ Đ], M. Rożyński

Department of Aquaculture

Inland Fisheries Institute in Olsztyn, Oczapowskiego 10

10-719 Olsztyn, Poland

K. Demska-Zakęś, E. Ziomek

Department of Ichthyology, University of Warmia and Mazury, Olsztyn, Poland

\section{Szczepkowski}

Department of Sturgeon Fish Breeding

Inland Fisheries Institute in Olsztyn, Pieczarki 50, 11-610 Pozezdrze, Poland
}

Diet and sex had significant impacts on the values of the pikeperch hepatosomatic index (HSI), hepatocyte size and that of their nuclei, and the values of the nucleocytoplasmic index (NCI).

Keywords: biochemical blood profiles, diet, pikeperch, recirculating aquaculture systems, sex

\section{Introduction}

A variety of factors that are either exogenous (e.g., water temperature, oxygen concentration, $\mathrm{pH}$, pollution, diet, etc.) or endogenous (e.g., fish species, age, sex, reproductive cycle, condition, state of health) impact the physiological condition of fish (Folmar 1993, Çelik 2004, Movahed et al. 2012, Akrami et al. 2013). A variety of diagnostic methods can be used to evaluate this comprehensively. Hematological and blood biochemical profiles are highly objective and simple to perform because collecting study material is minimally invasive. In addition to many important functions, including transport, homeostasis, and hemostasis, blood facilitates communication among various tissues and systems. This is why disruptions occurring in any of the internal organs can impact the values of various 
hematological and/or blood biochemical indicators. In addition to evaluating the condition and health status of fish, analyzing these parameters permits monitoring, among other factors, the effects of different types of stress and the impact of the environment or biological behavior (Çelik 2004, Akrami et al. 2013). The data obtained can be useful in work on determining optimal rearing parameters for different fish species that can ensure, among other things, fish welfare, rapid somatic growth, and increased immunity (Zutshi et al. 2010).

Knowledge about the state of fish health and interactions between environmental factors and fish are especially important in intensive culture systems such as recirculating aquaculture systems (RAS) and when new species are introduced into such systems. Percidae are one such new family with possible potential, and one species among them is pikeperch (Sander lucioperca (L.)). Methods for producing this species in RAS have been under development for the past several years (FAO 2012, Zakęś et al. 2012). The body of knowledge regarding the intensive production of pikeperch and the impact of the type of rearing on the biology and the physiological state of the species is rich (FAO 2012). However, information is lacking on the impact of intense feeding on the physiological and health status of pikeperch, i.e., hematological and blood biochemical indicators, which are highly significant in light of the fact that this species is fed most frequently a diet of high-energy trout feed (Schulz et al. 2006). Any potential impact sex might have on these parameters has not been analyzed either, while other studies indicate there are dependencies between sex and some indexes for somatic growth and slaughter yield (Zakęś et al. 2012).

The aim of the current study was to determine the impact diet (two commercial feeds formulated with different proximate compositions) and sex had on pikeperch hematological and blood plasma biochemical profiles and liver histology.

\section{Materials and methods}

\section{Fish and rearing conditions}

The experimental pikeperch material was fish obtained through out-of-season spawning and rearing of larval and juvenile stages in RAS. After 28 months of rearing, 56 specimens were selected (28 males and 28 females with mean body weights of approximately $1.35 \mathrm{~kg}$ ). The sex of the fish was determined in vivo using sex cells collected with catheters (Zakęś 2007). The fish were tagged with individual passive integrated transponders (PIT; Fish Eagle, Lechlade, Great Britain) using the intraperitoneal implantation method (Hopko et al. 2010). The tagged specimens were divided into two experimental groups ( 28 fish in each group, 14 males and 14 females). The groups were stocked into separate rearing tanks measuring $2.0(\mathrm{~L}) \times 2.0(\mathrm{~W}) \times 0.8 \mathrm{~m}(\mathrm{H})$ in a RAS. The initial stock biomass was $20 \mathrm{~kg} \mathrm{~m}^{-3}$. During rearing the mean water temperature was $21.2 \pm 1.7^{\circ} \mathrm{C}$. The oxygen concentration at the outflow did not drop below $5.8 \mathrm{mg} \mathrm{O}_{2} \mathrm{I}^{-1}$, while the concentration of total ammonia nitrogen $\left(\mathrm{TAN}=\mathrm{NH}_{4}{ }^{+}-\mathrm{N}+\mathrm{NH}_{3}-\mathrm{N}\right)$ did not exceed $0.12 \mathrm{mg} \mathrm{TAN}^{-1}$, and water $\mathrm{pH}$ fluctuated between 7.1 and 7.5. Water temperature and oxygen concentration were monitored daily, while TAN and $\mathrm{pH}$ were monitored weekly. The photoperiod applied was 24L:0D, and the light concentration measured at the tank water surfaces ranged from 10 to $20 \mathrm{~lx}$.

\section{Feeding and feed proximate composition}

The fish from each experimental group were fed formulated feeds with a granule size of $8 \mathrm{~mm}$. Two feeds with different proximate compositions were used (protein/lipids/nitrogen-free extracts $(\mathrm{P} / \mathrm{L} / \mathrm{NFE})$ ). The composition of the feed group I received was P505/L118/NFE294 $\mathrm{g} \mathrm{kg}^{-1}$, while that group II received was P471/L141/NFE290 $\mathrm{g} \mathrm{kg}^{-1}$ (Table 1). The fish were fed $12 \mathrm{~h} \mathrm{~d}^{-1}$ (19:00-07:00) using an automatic band feeder (4305 FIAP, Fishtechnic GmbH, Ursensollen, Germany). The daily feed ration was 
Table 1

Proximate composition ( $\mathrm{g} \mathrm{kg}^{-1}$ dry weight) and gross energy of feeds used in the study (for details see Materials and methods section)

\begin{tabular}{|c|c|c|}
\hline \multirow[b]{2}{*}{ Specification } & \multicolumn{2}{|l|}{ Diets } \\
\hline & group I & group II \\
\hline Crude protein & 505 & 471 \\
\hline Crude lipids & 118 & 141 \\
\hline Nitrogen-free extract (NFE) & 294 & 290 \\
\hline Crude fiber & 21 & 8 \\
\hline Crude ash & 62 & 90 \\
\hline Gross energy (MJ kg ${ }^{-1}$ feed) & 21.3 & 20.7 \\
\hline
\end{tabular}

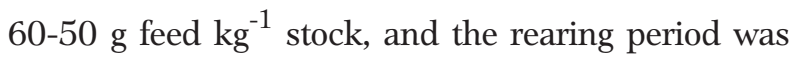
109 days.

The total protein content of both feeds was determined with the Kjeldahl method using a nitrogen to protein conversion coefficient of 6.25. The raw lipid content was determined with the Soxhlet method, while ash was determined after samples had been mineralized at $600^{\circ} \mathrm{C}$ (AOAC 1990). The content of nitrogen-free extract (NFE) was calculated as the difference of $100-$ (water + lipid + protein + ash) (Shearer 1994). The calorific values of the feed were determined with a C2000 basic calorimeter (IKA-Werke Gmbh \& Co. KG, Staufen, Germany).

\section{Measurements of individual fish and sampling}

Fish body weight (BW $\pm 1 \mathrm{~g})$, total length $(\mathrm{TL} \pm 0.1$ $\mathrm{cm})$ were measured at the beginning and the end of the experiment. All research procedures (fish measurements, blood and tissue sampling) were performed after the fish had been anesthetized in an aqueous solution of etomidate (Propiscin, IFI Olsztyn, Poland) at a dose of $1.5 \mathrm{ml} \mathrm{l}^{-1}$. Ten fish from each group were selected for hematological, biochemical, and histological analyses (group I - 6 females and 4 males, group II - 5 females and 5 males). After these specimens were anesthetized, their blood was drawn, they were decapitated, and their livers were sampled.

\section{Blood biochemical and hematological analyses}

A minimum of $4 \mathrm{ml}$ of blood was drawn from each specimen from the caudal vein with a sterile syringe and needle. The anticoagulant used was sodium heparin (1\%). A part of each blood sample was centrifuged at $9000 \times g$ for $3 \mathrm{~min}$ in a StatSpin ${ }^{\circledR}$ VT centrifuge (Idexx Laboratories Inc., USA) to obtain plasma for biochemical analysis. The rest of the blood was used for hematological analyses.

A VetTest ${ }^{\circledR}$ Chemistry Analyzer (Idexx Laboratories Inc., USA) was used to determine the following plasma biochemical parameters: glucose level $\left(\mathrm{Glu}-\mathrm{mmol} \mathrm{l}^{-1}\right)$, cholesterol $\left(\mathrm{Chol}-\mathrm{mmol} \mathrm{l}^{-1}\right)$, and total protein $\left(\mathrm{TP}-\mathrm{g} \mathrm{l}^{-1}\right)$, alkaline phosphatase activity $\left(\mathrm{ALP}-\mathrm{IU} \mathrm{l}^{-1}\right)$, and aspartate aminotransferase (AST - IU l ${ }^{-1}$ ).

The microhematocrit technique was used to determine hematocrit levels $\left(\mathrm{Ht}-\mathrm{ll}^{-1}\right)$ after the blood had been centrifuged in heparinized capillary tubes at $6000 \times g$ for $5 \mathrm{~min}$. Blood hemoglobin levels $(\mathrm{Hb}-$ $\mathrm{g} \mathrm{l}^{-1}$ ) were determined with the cyanmethemoglobin method (Blaxhall and Daisley 1973, Geiger et al. 2001). The concentration of hemoglobin in the blood was calculated with the following formula: $\mathrm{Hb}=\left(\mathrm{E}_{\mathrm{p}}\right.$ $\times \mathrm{W}) \times \mathrm{E}_{\mathrm{w}}^{-1}\left(\mathrm{E}_{\mathrm{p}}\right.$ - sample extinction; $\mathrm{W}$ - conversion factor for the current cyanmethemoglobin pattern; $\mathrm{E}_{\mathrm{w}}$ - cyanmethemoglobin standard extinction). The numbers of erythrocytes (RBC $\left.-\times 10^{6} \mu \mathrm{l}^{-1}\right)$ and leukocytes (WBC $-\times 10^{3} \mu \mathrm{l}^{-1}$ ) were counted manually using a Neubauer hemocytometer. These data were used to calculate the following red blood cell parameters: mean corpuscular volume (MCV; fl), mean corpuscular hemoglobin (MCH; pg), mean corpuscular hemoglobin concentration (MCHC; $\mathrm{g} \mathrm{l}^{-1}$ ) (Svobodová et al. 1991).

\section{Histology procedures}

After the conclusion of the experiment, the livers of all specimens were excised and weighed (LW \pm $0.01 \mathrm{~g}$ ) to determine the hepatosomatic index (HSI; $\%)=100 \times\left(\mathrm{LW} \times \mathrm{BW}^{-1}\right) ; \mathrm{LW}-$ liver weight $(\mathrm{g})$; 
BW - fish body weight (g). Then samples of the livers were collected for histological analyses. After the samples were fixed in Bouin solution, they were dehydrated in ethanol and xylene, embedded in paraffin blocks, and then cut into $5 \mu \mathrm{m}$ sections with a rotary microtome (Leica, Bensheim, Germany). The sections were affixed to degreased glass slides, dried, and then stained with hematoxylin and eosin. These preparations were analyzed under a light microscope (Nikon Eclipse E600, Japan). MultiScanBase v. 8.08 (Computer Scanning System Ltd., Warsaw, Poland) was used with each preparation from the different specimens to measure $( \pm 0.01 \mu \mathrm{m})$ the diameter of 50 hepatocytes $(\mathrm{C})$ and their nuclei $(\mathrm{N})$, and then the nucleocytoplasmic index (NCI) was calculated $\left(\mathrm{NCI}=\mathrm{N} \times \mathrm{C}^{-1}\right)$.

\section{Statistical analysis}

The results obtained were analyzed statistically with Statistica 8.0 (StatSoft, Inc., USA). Data were tested for the normal distribution using Shapiro-Wilk test. The homogeneity of variance was analyzed using Levene's test. Values expressed as percentages were transformed using arcsin prior to statistical analysis. Two-way analysis of variance MANOVA (diet (D) $\times$ fish sex (S)) was used to assess the statistical significance of differences among groups at a significance level of $\mathrm{P} \leq 0.05$.

\section{Results}

At the conclusion of the experiment the fish had attained a mean body weight of approximately $2.0 \mathrm{~kg}$. Neither diet nor sex had a significant impact on this rearing parameter $(\mathrm{P}>0.05)$. The diets applied also did not significantly impact the analyzed pikeperch blood plasma biochemical parameters, i.e., glucose (Glu), cholesterol (Chol), total protein (TP), or alkaline phosphatase (ALP) and aspartate aminotransferase (AST) activity $(\mathrm{P}>0.05$; Table 2). A dependence was determined between fish sex and the plasma Glu and Chol levels (Table 2). Plasma Glu levels were higher in males than in females, but Chol levels were lower $(\mathrm{P}<0.05)$.

Feeding the fish the feeds tested had a significant impact on the hematological values of hematocrit $(\mathrm{Ht})$, hemoglobin $(\mathrm{Hb})$ and mean corpuscular hemoglobin $(\mathrm{MCH})(\mathrm{P}<0.05$; Table 3$)$. Higher values of these indicators were noted in fish fed the diet with the higher protein content (group I; Tables 1, 3). Moreover, differences in the values of all the hematological indicators analyzed were noted in both groups

Table 2

Final blood plasma biochemical profile of pikeperch reared in RAS (mean ( \pm SD)) (for details see Materials and methods section)

\begin{tabular}{|c|c|c|c|c|c|c|c|c|c|c|}
\hline \multirow[b]{2}{*}{ Parameters } & \multirow[b]{2}{*}{ Unit } & \multicolumn{3}{|l|}{ Group I } & \multicolumn{3}{|l|}{ Group II } & \multicolumn{3}{|c|}{$\begin{array}{l}\text { MANOVA, value of } P \text { and } \\
\text { F-statistic }\end{array}$} \\
\hline & & $\begin{array}{l}\text { females } \\
(\mathrm{n}=6)\end{array}$ & $\begin{array}{l}\text { males } \\
(\mathrm{n}=4)\end{array}$ & $\begin{array}{l}\text { together } \\
(\mathrm{n}=10)\end{array}$ & $\begin{array}{l}\text { females } \\
(\mathrm{n}=6)\end{array}$ & $\begin{array}{l}\text { males } \\
(\mathrm{n}=4)\end{array}$ & $\begin{array}{l}\text { together } \\
(\mathrm{n}=10)\end{array}$ & $\operatorname{sex}(\mathrm{S})$ & $\operatorname{diet}(\mathrm{D})$ & $\mathrm{S} \times \mathrm{D}$ \\
\hline Glu & $\mathrm{mmol} \mathrm{l}^{-1}$ & $\begin{array}{l}5.36 \\
( \pm 0.11)\end{array}$ & $\begin{array}{l}5.63 \\
( \pm 0.12)\end{array}$ & $\begin{array}{l}5.46 \\
( \pm 0.18)\end{array}$ & $\begin{array}{l}5.34 \\
( \pm 0.05)\end{array}$ & $\begin{array}{l}5.60 \\
( \pm 0.11)\end{array}$ & $\begin{array}{l}5.47 \\
( \pm 0.16)\end{array}$ & $\begin{array}{l}0.0000 \\
34.270\end{array}$ & $\begin{array}{l}0.6962 \\
0.160\end{array}$ & $\begin{array}{l}0.9134 \\
0.010\end{array}$ \\
\hline Chol & $\mathrm{mmol} \mathrm{l}^{-1}$ & $\begin{array}{l}2.55 \\
( \pm 0.11)\end{array}$ & $\begin{array}{l}2.42 \\
( \pm 0.08)\end{array}$ & $\begin{array}{l}2.49 \\
( \pm 0.11)\end{array}$ & $\begin{array}{l}2.60 \\
( \pm 0.12)\end{array}$ & $\begin{array}{l}2.40 \\
( \pm 0.03)\end{array}$ & $\begin{array}{l}2.50 \\
( \pm 0.13)\end{array}$ & $\begin{array}{l}0.0014 \\
14.880\end{array}$ & $\begin{array}{l}0.6383 \\
0.230\end{array}$ & $\begin{array}{l}0.4684 \\
0.550\end{array}$ \\
\hline $\mathrm{TP}$ & $\mathrm{g} \mathrm{l}^{-1}$ & $\begin{array}{l}50.35 \\
( \pm 1.64)\end{array}$ & $\begin{array}{l}48.93 \\
( \pm 1.74)\end{array}$ & $\begin{array}{l}49.78 \\
( \pm 1.74)\end{array}$ & $\begin{array}{l}50.16 \\
( \pm 1.63)\end{array}$ & $\begin{array}{l}48.96 \\
( \pm 1.19)\end{array}$ & $\begin{array}{l}49.56 \\
( \pm 1.49)\end{array}$ & $\begin{array}{l}0.0807 \\
3.480\end{array}$ & $\begin{array}{l}0.9137 \\
0.010\end{array}$ & $\begin{array}{l}0.8750 \\
0.030\end{array}$ \\
\hline ALP & $\mathrm{IU} \mathrm{l}^{-1}$ & $\begin{array}{l}2.29 \\
( \pm 0.96)\end{array}$ & $\begin{array}{l}2.93 \\
( \pm 0.72)\end{array}$ & $\begin{array}{l}2.55 \\
( \pm 0.90)\end{array}$ & $\begin{array}{l}2.26 \\
( \pm 0.36)\end{array}$ & $\begin{array}{l}2.93 \\
( \pm 0.61)\end{array}$ & $\begin{array}{l}2.60 \\
( \pm 0.59)\end{array}$ & $\begin{array}{l}0.0603 \\
4.085\end{array}$ & $\begin{array}{l}0.9671 \\
0.002\end{array}$ & $\begin{array}{l}0.9779 \\
0.001\end{array}$ \\
\hline AST & $\mathrm{IU} \mathrm{l}^{-1}$ & $\begin{array}{l}24.29 \\
( \pm 3.07)\end{array}$ & $\begin{array}{l}25.53 \\
( \pm 5.14)\end{array}$ & $\begin{array}{l}24.79 \\
( \pm 3.80)\end{array}$ & $\begin{array}{l}23.11 \\
( \pm 1.18)\end{array}$ & $\begin{array}{l}26.16 \\
( \pm 3.40)\end{array}$ & $\begin{array}{l}24.63 \\
( \pm 2.89)\end{array}$ & $\begin{array}{l}0.1740 \\
2.022\end{array}$ & $\begin{array}{l}0.8568 \\
0.034\end{array}$ & $\begin{array}{l}0.5542 \\
0.365\end{array}$ \\
\hline
\end{tabular}


Table 3

Final hematological indexes of the blood of pikeperch reared in RAS (mean ( \pm SD)) (for details see Materials and methods section)

\begin{tabular}{|c|c|c|c|c|c|c|c|c|c|c|}
\hline \multirow[b]{2}{*}{$\begin{array}{l}\text { Parame- } \\
\text { ters }\end{array}$} & \multirow[b]{2}{*}{ Unit } & \multicolumn{3}{|l|}{ Group I } & \multicolumn{3}{|l|}{ Group II } & \multicolumn{3}{|c|}{$\begin{array}{l}\text { MANOVA, value of } P \text { and } \\
\text { F-statistic }\end{array}$} \\
\hline & & $\begin{array}{l}\text { females } \\
(\mathrm{n}=6)\end{array}$ & $\begin{array}{l}\text { males } \\
(\mathrm{n}=4)\end{array}$ & $\begin{array}{l}\text { together } \\
(\mathrm{n}=10)\end{array}$ & $\begin{array}{l}\text { females } \\
(\mathrm{n}=5)\end{array}$ & $\begin{array}{l}\text { males } \\
(\mathrm{n}=5)\end{array}$ & $\begin{array}{l}\text { together } \\
(\mathrm{n}=10)\end{array}$ & $\operatorname{sex}(S)$ & $\operatorname{diet}(\mathrm{D})$ & $\mathrm{S} \times \mathrm{D}$ \\
\hline $\mathrm{Ht}$ & $11^{-1}$ & $\begin{array}{l}0.38 \\
( \pm 0.02)\end{array}$ & $\begin{array}{l}0.42 \\
( \pm 0.02)\end{array}$ & $\begin{array}{l}0.39 \\
( \pm 0.03)\end{array}$ & $\begin{array}{l}0.37 \\
( \pm 0.02)\end{array}$ & $\begin{array}{l}0.38 \\
( \pm 0.03)\end{array}$ & $\begin{array}{l}0.37 \\
( \pm 0.02)\end{array}$ & $\begin{array}{l}0.0263 \\
5.986\end{array}$ & $\begin{array}{l}0.0459 \\
4.684\end{array}$ & $\begin{array}{l}0.2063 \\
1.736\end{array}$ \\
\hline $\mathrm{Hb}$ & $\mathrm{gl}^{-1}$ & $\begin{array}{l}45.22 \\
( \pm 4.41)\end{array}$ & $\begin{array}{l}66.16 \\
( \pm 4.18)\end{array}$ & $\begin{array}{l}53.59 \\
( \pm 11.56)\end{array}$ & $\begin{array}{l}46.21 \\
( \pm 2.63)\end{array}$ & $\begin{array}{l}52.45 \\
( \pm 5.01)\end{array}$ & $\begin{array}{l}49.33 \\
( \pm 5.00)\end{array}$ & $\begin{array}{l}0.0000 \\
52.092\end{array}$ & $\begin{array}{l}0.0038 \\
11.400\end{array}$ & $\begin{array}{l}0.0013 \\
15.240\end{array}$ \\
\hline WBC & $\times 10^{3} \mu \mathrm{l}^{-1}$ & $\begin{array}{l}15.42 \\
( \pm 1.38)\end{array}$ & $\begin{array}{l}17.06 \\
( \pm 0.74)\end{array}$ & $\begin{array}{l}16.08 \\
( \pm 1.39)\end{array}$ & $\begin{array}{l}15.03 \\
( \pm 1.49)\end{array}$ & $\begin{array}{l}16.50 \\
( \pm 0.54)\end{array}$ & $\begin{array}{l}15.77 \\
( \pm 1.31)\end{array}$ & $\begin{array}{l}0.0085 \\
8.9810\end{array}$ & $\begin{array}{l}0.3762 \\
0.8290\end{array}$ & $\begin{array}{l}0.8688 \\
0.0280\end{array}$ \\
\hline $\mathrm{RBC}$ & $\times 10^{6} \mu \mathrm{l}^{-1}$ & $\begin{array}{l}1.76 \\
( \pm 0.11)\end{array}$ & $\begin{array}{l}1.86 \\
( \pm 0.12)\end{array}$ & $\begin{array}{l}1.80 \\
( \pm 0.12)\end{array}$ & $\begin{array}{l}1.77 \\
( \pm 0.05)\end{array}$ & $\begin{array}{l}1.80 \\
( \pm 0.07)\end{array}$ & $\begin{array}{l}1.79 \\
( \pm 0.06)\end{array}$ & $\begin{array}{l}0.1694 \\
2.071\end{array}$ & $\begin{array}{l}0.5974 \\
0.290\end{array}$ & $\begin{array}{l}0.3969 \\
0.758\end{array}$ \\
\hline MCV & $\mathrm{fl}$ & $\begin{array}{l}214 \\
( \pm 14)\end{array}$ & $\begin{array}{l}224 \\
( \pm 23)\end{array}$ & $\begin{array}{l}218 \\
( \pm 18)\end{array}$ & $\begin{array}{l}205 \\
( \pm 10)\end{array}$ & $\begin{array}{l}210 \\
( \pm 11)\end{array}$ & $\begin{array}{l}208 \\
( \pm 11)\end{array}$ & $\begin{array}{l}0.2731 \\
1.288\end{array}$ & $\begin{array}{l}0.1176 \\
2.737\end{array}$ & $\begin{array}{l}0.6780 \\
0.179\end{array}$ \\
\hline $\mathrm{MCH}$ & pg & $\begin{array}{l}25.76 \\
( \pm 2.98)\end{array}$ & $\begin{array}{l}35.71 \\
( \pm 4.68)\end{array}$ & $\begin{array}{l}29.74 \\
( \pm 6.22)\end{array}$ & $\begin{array}{l}26.08 \\
( \pm 1.62)\end{array}$ & $\begin{array}{l}29.12 \\
( \pm 2.12)\end{array}$ & $\begin{array}{l}27.60 \\
( \pm 2.39)\end{array}$ & $\begin{array}{l}0.0002 \\
23.836\end{array}$ & $\begin{array}{l}0.0315 \\
5.552\end{array}$ & $\begin{array}{l}0.0193 \\
6.759\end{array}$ \\
\hline $\mathrm{MCHC}$ & $\mathrm{gl}^{-1}$ & $\begin{array}{l}120.5 \\
( \pm 7.9) \\
\end{array}$ & $\begin{array}{l}159.7 \\
( \pm 11.3) \\
\end{array}$ & $\begin{array}{l}136.2 \\
( \pm 22.1)\end{array}$ & $\begin{array}{l}126.4 \\
( \pm 7.0) \\
\end{array}$ & $\begin{array}{l}138.7 \\
( \pm 5.0) \\
\end{array}$ & $\begin{array}{l}132.5 \\
( \pm 8.6) \\
\end{array}$ & $\begin{array}{l}0.0018 \\
13.875 \\
\end{array}$ & $\begin{array}{l}0.1809 \\
1.958 \\
\end{array}$ & $\begin{array}{l}0.0018 \\
13.875 \\
\end{array}$ \\
\hline
\end{tabular}

Table 4

Final cytological indexes of the liver of pikeperch reared in RAS (mean $( \pm$ SD)) (for details see Materials and methods section)

\begin{tabular}{|c|c|c|c|c|c|c|c|c|c|c|}
\hline \multirow[b]{2}{*}{$\begin{array}{l}\text { Parame- } \\
\text { ters }\end{array}$} & \multirow[b]{2}{*}{ Unit } & \multicolumn{3}{|l|}{ Group I } & \multicolumn{3}{|l|}{ Group II } & \multicolumn{3}{|c|}{$\begin{array}{l}\text { MANOVA, value of } P \text { and } \\
\text { F-statistic }\end{array}$} \\
\hline & & $\begin{array}{l}\text { females } \\
(\mathrm{n}=6)\end{array}$ & $\begin{array}{l}\text { males } \\
(\mathrm{n}=4)\end{array}$ & $\begin{array}{l}\text { together } \\
(\mathrm{n}=10)\end{array}$ & $\begin{array}{l}\text { females } \\
(\mathrm{n}=6)\end{array}$ & $\begin{array}{l}\text { males } \\
(\mathrm{n}=4)\end{array}$ & $\begin{array}{l}\text { together } \\
(\mathrm{n}=10)\end{array}$ & $\operatorname{sex}(S)$ & $\operatorname{diet}(\mathrm{D})$ & $\mathrm{S} \times \mathrm{D}$ \\
\hline HSI & $\%$ & $\begin{array}{l}1.76 \\
( \pm 0.26)\end{array}$ & $\begin{array}{l}1.42 \\
( \pm 0.40)\end{array}$ & $\begin{array}{l}1.62 \\
( \pm 0.35)\end{array}$ & $\begin{array}{l}1.44 \\
( \pm 0.29)\end{array}$ & $\begin{array}{l}1.17 \\
( \pm 0.13)\end{array}$ & $\begin{array}{l}1.31 \\
( \pm 0.25)\end{array}$ & $\begin{array}{l}0.0278 \\
5.8540\end{array}$ & $\begin{array}{l}0.0383 \\
5.0974\end{array}$ & $\begin{array}{l}0.7541 \\
0.1016\end{array}$ \\
\hline $\begin{array}{l}\text { Size of } \\
\text { hepatocyte }\end{array}$ & $\mu \mathrm{m}$ & $\begin{array}{l}13.97 \\
( \pm 1.45)\end{array}$ & $\begin{array}{l}15.87 \\
( \pm 0.99)\end{array}$ & $\begin{array}{l}14.73 \\
( \pm 1.57)\end{array}$ & $\begin{array}{l}12.78 \\
( \pm 0.46)\end{array}$ & $\begin{array}{l}15.52 \\
( \pm 0.39)\end{array}$ & $\begin{array}{l}14.15 \\
( \pm 1.5)\end{array}$ & $\begin{array}{l}0.0001 \\
28.188\end{array}$ & $\begin{array}{l}0.0952 \\
3.143\end{array}$ & $\begin{array}{l}0.3496 \\
0.928\end{array}$ \\
\hline $\begin{array}{l}\text { Size of } \\
\text { nuclei }\end{array}$ & $\mu \mathrm{m}$ & $\begin{array}{l}5.2 \\
( \pm 0.21)\end{array}$ & $\begin{array}{l}4.84 \\
( \pm 0.15)\end{array}$ & $\begin{array}{l}5.05 \\
( \pm 0.26)\end{array}$ & $\begin{array}{l}5.38 \\
( \pm 0.19)\end{array}$ & $\begin{array}{l}4.99 \\
( \pm 0.13)\end{array}$ & $\begin{array}{l}5.19 \\
( \pm 0.25)\end{array}$ & $\begin{array}{l}0.0003 \\
21.890\end{array}$ & $\begin{array}{l}0.0518 \\
4.420\end{array}$ & $\begin{array}{l}0.9092 \\
0.010\end{array}$ \\
\hline $\mathrm{NCI}$ & - & $\begin{array}{l}0.38 \\
( \pm 0.04)\end{array}$ & $\begin{array}{l}0.31 \\
( \pm 0.02)\end{array}$ & $\begin{array}{l}0.35 \\
( \pm 0.05)\end{array}$ & $\begin{array}{l}0.43 \\
( \pm 0.02)\end{array}$ & $\begin{array}{l}0.33 \\
( \pm 0.01)\end{array}$ & $\begin{array}{l}0.38 \\
( \pm 0.06)\end{array}$ & $\begin{array}{l}0.0000 \\
41.778\end{array}$ & $\begin{array}{l}0.0283 \\
5.810\end{array}$ & $\begin{array}{l}0.2765 \\
1.269\end{array}$ \\
\hline
\end{tabular}

with regard to fish sex. They were higher in males, and statistically significant differences were confirmed for $\mathrm{Ht}, \mathrm{Hb}$, leukocytes (WBC), and two red blood cell indicators $-\mathrm{MCH}$ and $\mathrm{MCHC}(\mathrm{P}<0.05$; Table 3).

Diet and sex were confirmed to have a significant impact on pikeperch hepatosomatic index (HSI) values. The HSI values of fish from group I were approximately $20 \%$ higher in comparison to group II (P $<0.05$, Table 4). Significantly higher HSI values were noted in the females from both groups $(\mathrm{P}<0.05$, Table 4). Fish sex also determined the size of hepatocytes and their nuclei and the values of the nucleocytoplasmic index $(\mathrm{P}<0.05$; Table 4$)$. While 
the size of the hepatocytes was statistically larger in males, those of the females were characterized by significantly larger nuclei. Consequently, the values of the nucleocytoplasmic index were higher in the females from both feed groups. Diet also had a significant impact on this index $(\mathrm{P}<0.05$; Table 4$)$.

\section{Discussion}

While hematological and blood biochemical tests are quick, reliable tools for evaluating the health and condition of fish, differences in the various indexes among species and individuals are very high (Folmar 1993). The results obtained in the current study are similar to the blood parameters of pikeperch from intensive rearing systems (Kristan et al. 2012) and from open waters (Ivanc et al. 1994, Movahed et al. 2012). It should be noted that the size of the fish used in the present study was similar to that of pikeperch from the Tisza River, Hungary (Ivanc et al. 1994) and the Anzali Lagoon, Iran (Movahed et al. 2012), while cultured pikeperch were substantially smaller (Kristan et al. 2012).

In the literature, diet is one of the most frequently mentioned factors impacting, among other things, biochemical and hematological parameters, and consequently fish health status and condition (Patriche et al. 2009). In the present study, diet was not noted to have a significant impact on the analyzed pikeperch blood plasma biochemical indexes, including the levels of glucose (Glu), cholesterol (Chol), protein, or ALP and AST enzymatic activity. However, in the pikeperch from group I that were fed a diet with a higher content of protein, the values of all the hematological indexes analyzed were higher, and the intergroup variation was statistically significant in the case of three of them - Ht, $\mathrm{Hb}$, and $\mathrm{MCH}$. Bicudo et al. (2009), in a study of Piaractus mesopotamicus (Holmberg), also observed increases in blood hemoglobin and moderate hemoglobin concentrations in erythrocytes as nutritional values of the feed increased. However, in Siberian sturgeon (Acipenser baerii Brandt) fed feed with higher protein content increased numbers of erythrocytes and higher hemoglobin and hematocrit levels were noted (Docan et al. 2011). Greater weight gain and improved overall physiological status were also noted among sturgeon studied (Docan et al. 2011). Although no significant difference was noted in the final body weight of the pikeperch, feeding the fish feed with higher protein content impacted the liver weight which resulted in higher values of the hepatosomatic index (HSI).

While diet did not significantly impact the analyzed pikeperch blood plasma biochemical indexes, fish sex was a significant determinant factor of the level of some of them, specifically of glucose and cholesterol. Glucose plays a key nutritional role during the reproductive period. Lower concentrations of this monosaccharide in the blood plasma of female pikeperch could be linked with the slightly different way it is deposited in the tissues. In females glucose is deposited primarily in the fat cells and ovarian tissues that use substantially larger reserves of this sugar than do the tissues of the male testes (Washburn et al. 1992), which is why its blood concentration is lower. The results regarding cholesterol were different; the level of this compound in female blood plasma was significantly higher than in males. Generally, cholesterol is essential to proper body function. It is the substrate for the synthesis of many important, active biological compounds, including sex hormones and corticosteroids. Concentrations of these compounds during the reproductive period increases substantially, especially in females. Moreover, increased levels of cholesterol and lipids in the blood, which reach the highest concentrations in the final maturation phase of the oocytes, is well documented in the pre-spawning and spawning periods (Chatzifotis et al. 2004, Yeganeh 2012). The results obtained in the present study provide evidence regarding the rapid metabolic rate and the higher reproductive costs of females, which corresponds also to higher parameters of daily growth rates (DGR) and specific growth rates (SGR) and in higher values of the gonadosomatic index (GSI) (Zakęś et al. 2012) and the hepatosomatic index (HSI) (current study). 
In mammals the correlation between the hematological profile and sex is widely known (Stankiewicz 1973). To date, such a correlation has not been observed in many fish species (Khadjeh et al. 2010, Karimi et al. 2013). The results of our study indicate that, in the case of pikeperch, sex determines the value of hematological indexes. The analyses indicate that the values of all the parameters studied were higher in males, although the differences were statistically significant for $\mathrm{Ht}, \mathrm{Hb}, \mathrm{MCH}$ and MCHC. The immediate cause of the increased values of these parameters in males could be erythropoietin. It has been demonstrated that the activity of this glycoprotein hormone, which is responsible for stimulating the creation of erythrocytes that deliver oxygen, increases under the influence of the sex hormones, especially testosterone (Golemi et al. 2013). This is extraordinarily important because of the more active male reproductive behavior (Pradhan et al. 2012, 2013), and the associated intensification in metabolic processes and increased oxygen requirements (Golemi et al. 2013). In turn, the large amounts of energy required for the growth and maturation of oocytes can influence the condition of females and cause lowered immunity (Kapila et al. 2000). This disadvantageous phenomenon could be compensated for by the higher leukocyte production noted in females than in males, which has been confirmed in, among other species, Labeo rohita (Hamilton) and Tor putitora (Hamilton) (Kapila et al. 2000). However, our study indicated that the level of WBC in sexually mature pikeperch males was significantly higher than in females, which could have stemmed from the optimum rearing conditions in RAS and/or from the specifics of the species. This was also confirmed by the results of a study by Sarameh et al. (2013) in which slightly higher WBC values were noted in male of pikeperch.

\section{Conclusions}

In summation, feed proximate composition impacts the hematological, blood biochemical, and hepatic indexes of pikeperch reared in RAS. The variation observed among these parameters and the degree to which nutrients are used does not depend only on diet, but also on the sex of the fish. Probably this is associated with, among other things, how hormones are synthesized and distributed, the development and maturation of gonads and sex cells, and reproductive behavior. The current study provides valuable information regarding the hematological and blood plasma biochemical parameters of adult pikeperch reared in RAS. The results can be important for research on developing biotechniques for producing single sex stocks of this species, as well as for the development of pikeperch production in RAS in general.

Acknowledgments. The study was conducted within the framework of the research programmes of the Inland Fisheries Institute (No. S-028) and the University of Warmia and Mazury (No.0804-0809).

Author contributions. Z.Z., K.D.-Z. and M.S. - designed the research, Z.Z., K.D.-Z., M.R., E.Z., M.S. performed the research, Z.Z., M.R. - analyzed data, Z.Z., K.D-Z. - wrote the paper.

\section{References}

Akrami R., Gharaei A., Karami R. 2013 - Age and sex specific variation in hematological and serum biochemical parameters of Beluga (Huso huso Linnaeus, 1758) - Int. J. Aquat. Biol. 1: 132-137.

AOAC 1990 - Official methods of analysis of the association of official analytical chemists - Association of Official Analytical Chemists Publ., Washington, DC, 2044 p.

Bicudo A.J.A., Sado R.Y., Cyrino J.E.P. 2009 - Growth and haematology of pacu, Piaractus mesopotamicus, fed diets with varying protein to energy ratio - Aquac. Res. 40: 486-495.

Blaxhall P.C., Daisley K.W. 1973 - Routine hematology methods for use with fish blood - J. Fish Biol. 5: 771-781.

Çelik E. 2004 - Blood chemistry (electrolytes, lipoproteins and enzymes) values of black scorpion fish (Scorpaena porcus Linneaus 1758) in the Dardanelles - Turk. J. Biol. 4: 716-719.

Chatzifotis S., Muje P., Pavlidis M., Ågren J., Paalavuo M., Mölsä H. 2004 - Evolution of tissue composition and serum metabolites during gonadal development in the 
common dentex (Dentex dentex) - Aquaculture 236: 557-573.

Docan A., Dediu L., Cristea V. 2011 - Effect of feeding with different dietary protein level on hematological indices of juvenile Siberian sturgeon, Acipenser baeri reared under recirculating systems condition - AACL Bioflux 4: 180-186.

FAO 2012 - Cultured Aquatic Species Information Programme. Sander lucioperca - Available from: http://www.fao.org/fishery/culturedspecies/Sander_ lucioperca/en (accessed February 20, 2016).

Folmar L.C. 1993 - Effects of chemical contaminants on blood chemistry of teleost fish: a bibliography and synopsis of selected effects - Environ. Toxicol. Chem. 12: 337-375.

Geiger G., Bernhagen J., Wagner E., Bisswanger H., Brunner H., Vitzthum F. 2001 - Standardized measurements and differential spectroscopy in microplates - Anal. Biochem. 296: 29-40.

Golemi S., Medja N., Lacej D. 2013 - Influence of sex on the hematological and morphometric parameters of Cyprinus carpio (Linnaeus, 1758) from Shkodra Lake - Acad. J. Interdiscip. Stud. 2: 45-49.

Hopko M., Zakęś Z., Kowalska A., Partyka K. 2010 - Impact of intraperitoneal and intramuscular PIT tags on survival, growth, and tag retention in juvenile pikeperch, Sander lucioperca (L.) - Arch. Pol. Fish. 18: 85-92.

Ivanc A., Maletin S., Djukić N., Miljanović B. 1994 Ecophysiological interpretation of hematology of different Percidae species in the river Tisza - Tiscia 28: 53-56.

Kapila R., Kapila S., Basade Y. 2000 - Sex related haematological variations in Himalayan golden mahseer, Tor putitora (Ham.) - Ind. J. Fish. 47: 81-85.

Karimi S., Kochinian P., Salati A.P. 2013 - The effect of sexuality on some haematological parameters of the yellowfin seabream, Acanthopagrus latus in Persian Gulf - Iran. J. Vet. Res. 14: 65-68

Khadjeh G.H., Mesbah M., Nikmehr S., Sabzevarizadeh M. 2010 - Effect of sex on the haematological parameters of reared shirboat fish (Barbus grypus) - J. Vet. Res. 65: 217-224.

Kristan J., Stara A., Turek J., Policar T., Velisek J. 2012 Comparison of the effects of four anaesthetics on haematological and blood biochemical profiles in pikeperch (Sander lucioperca L.) - Neuroendocrinol. Let. 33: 66-71.

Movahed R., Khvara H., Havatbakhshi M.R., Rahbar M. 2012 - Some haematological changes of zander (Sander lucioperca) in relation to age and its relationship with parasitic infection - Fish. Aquac. J. 47: 1-7.

Patriche T., Patriche N., Tenciu M. 2009 - Cyprinids total blood proteins determination - Anim. Sci. Biotechnol. 42: 95-101.

Pradhan S.C., Patra A.K., Pal A. 2013 - Hematological and plasma chemistry of Indian major carp, Labeo rohita (Hamilton, 1822) - J. Appl. Ichthyol. 30: 48-54.

Pradhan S.C., Patra A.K., Sarkar B., Pal A. 2012 - Seasonal changes in hematological parameters of Catla catla (Hamilton, 1822) - Comp. Clinic. Pathol. 21: 1473-1481.

Sarameh S.P., Falahatkar B., Takami G.A., Efatpanah I. 2013 - Physiological changes in male and female pikeperch Sander lucioperca (Linnaeus, 1758) subjected to different photoperiods and handling stress during the reproductive season - Fish Physiol. Biochem. 39: 1253-1266.

Schulz C., Günther S., Wirth M., Rennert B. 2006 - Growth performance and body composition of pike perch (Sander lucioperca) fed varying formulated and natural diets Aquac. Int. 14: 577-586.

Shearer K.D. 1994 - Factors affecting the proximate composition of cultured fishes with emphasis on salmonids Aquaculture 119: 63-88.

Stankiewicz W. 1973 - Veterinary haematology - PWRiL, Warsaw, Poland, 422 p. (in Polish).

Svobodová Z., Pravda D., Paláčkova J. 1991 - Unified methods of haematological examination of fish. Methods No. 20 - Research Institute of Fish Culture and Hydrobiology, Vodňany, Czech Republic, 31 p.

Washburn B.S., Bruss M.L., Avery E.H., Freedland R.A. 1992 - Effects of estrogen on whole animal and tissue glucose use in female and male rainbow trout - Am. J. Physiol. 263: 1241-1247.

Yeganeh S. 2012 - Seasonal changes of blood serum biochemistry in relation to sexual maturation of female common carp - Comp. Clinic. Pathol. 21: 1059-1063.

Zakęś Z. 2007 - Out-of-season spawning of cultured pikeperch (Sander lucioperca (L.)) - Aquac. Res. 38: 1419-1427.

Zakęś Z., Szczepkowski M., Jankowska B., Kowalska A., Demska-Zakęś K. 2012 - Slaughter yield and growth performance indexes of pikeperch (Sander lucioperca (L.)) selects reared in recirculating aquaculture systems at suboptimal temperatures - Arch. Pol. Fish. 20: 281-288.

Zutshi B., Prasad S.G., Nagaraja R. 2010 - Alteration in hematology of Labeo rohita under stress of pollution from Lakes of Bangalore, Karnataka, India - Environ. Monit. Assess. 168: 11-19. 